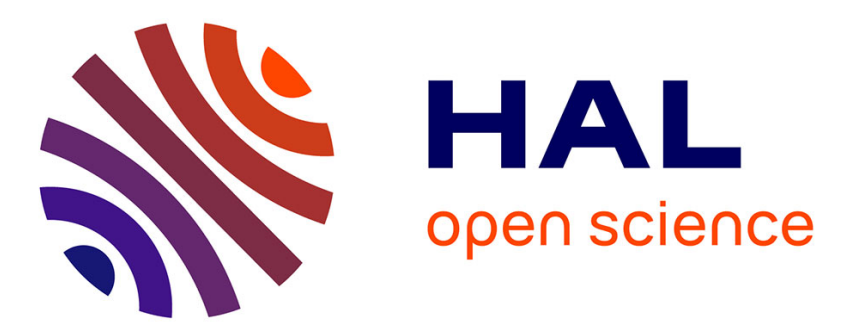

\title{
Ni 1-x Co x O y, Ni 1-x Co x S y and Ni 1-x Co x P y Catalysts Prepared from Ni 1-x Co x -ZIF-67 for Hydrogen Production by Electrolysis in Alkaline Media
}

Yuchen Cui, Zhi Liu, Hailing Guo, Yongming Chai, Chenguang Liu, Svetlana Mintova

\section{- To cite this version:}

Yuchen Cui, Zhi Liu, Hailing Guo, Yongming Chai, Chenguang Liu, et al.. Ni 1-x Co x O y, Ni 1-x Co x S y and Ni 1-x Co x P y Catalysts Prepared from Ni 1-x Co x-ZIF-67 for Hydrogen Production by Electrolysis in Alkaline Media. ChemCatChem, 2019, 11 (20), pp.5131-5138. 10.1002/cctc.201901385 . hal-02409856

\section{HAL Id: hal-02409856 https://hal.science/hal-02409856}

Submitted on 27 Nov 2020

HAL is a multi-disciplinary open access archive for the deposit and dissemination of scientific research documents, whether they are published or not. The documents may come from teaching and research institutions in France or abroad, or from public or private research centers.
L'archive ouverte pluridisciplinaire HAL, est destinée au dépôt et à la diffusion de documents scientifiques de niveau recherche, publiés ou non, émanant des établissements d'enseignement et de recherche français ou étrangers, des laboratoires publics ou privés. 


\section{$\mathrm{Ni}_{1-\mathrm{x}} \mathrm{Co}_{\mathrm{x}} \mathrm{O}_{\mathrm{y}}, \mathrm{Ni}_{1-\mathrm{x}} \mathrm{Co}_{\mathrm{x}} \mathrm{S}_{\mathrm{y}}$ and $\mathrm{Ni}_{1-\mathrm{x}} \mathrm{Co}_{\mathrm{x}} \mathrm{P}_{\mathrm{y}}$ catalysts prepared from $\mathrm{Ni}_{1-\mathrm{x}} \mathrm{Co}_{\mathrm{x}}-$}

\section{ZIF-67 for hydrogen production by electrolysis in alkaline media}

Yuchen Cui ${ }^{[a]}$, Zhi Liu ${ }^{[a]}$, Hailing Guo*[a], Yongming Chai ${ }^{[a]}$, Chenguang Liu ${ }^{[a]}$, Svetlana Mintova ${ }^{[a, b]}$

a State Key Laboratory of Heavy Oil Processing, Key Laboratory of Catalysis, China National Petroleum Corp. (CNPC) China University of Petroleum (East China), Qingdao 266555, People's Republic of China.

b Laboratoire Catalyse et Spectrochimie (LCS), Normandie University, ENSICAEN, UNICAEN, CNRS, 6 boulevard du Marechal Juin, 14050 Caen, France

* Corresponding author: Prof. Hailing Guo, Fax: +86 0532 86981787, Tel: +86 053286984688 and email: guohl@upc.edu.cn 
Abstract: The uniform homeotypic bimetallic $\mathrm{Ni}_{1-\mathrm{x}} \mathrm{Co}_{\mathrm{x}} \mathrm{O}_{\mathrm{y}}, \mathrm{Ni}_{1-\mathrm{x}} \mathrm{Co}_{\mathrm{x}} \mathrm{S}_{\mathrm{y}}$ and $\mathrm{Ni}_{1-\mathrm{x}} \mathrm{Co}_{\mathrm{x}} \mathrm{P}_{\mathrm{y}}$ catalysts were synthesized from $\mathrm{Ni}_{1-\mathrm{x}} \mathrm{Co}_{\mathrm{x}}-\mathrm{ZIF}-67$ crystals $(120-135 \mathrm{~nm})$ reacting with oxygen, sublimed sulfur and sodium hypophosphite, respectively under control conditions. The catalysts were deposited on glassy carbon electrode (GCE), and their electro-catalytic activity for hydrogen production in alkaline media by electrolysis was investigated. The electrocatalytic activity of the catalysts towards hydrogen evolution reaction (HER) decreased in the following order $\mathrm{Ni}_{0.1} \mathrm{Co}_{0.9} \mathrm{P}_{\mathrm{y}}>\mathrm{Ni}_{0.2} \mathrm{Co}_{0.8} \mathrm{O}_{\mathrm{y}}>\mathrm{Ni}_{0.5} \mathrm{Co}_{0.5} \mathrm{~S}_{\mathrm{y}}>\mathrm{Ni}_{0.1} \mathrm{Co}_{0.9}-\mathrm{ZIF}-$ 67. The $\mathrm{Ni}_{0.1} \mathrm{Co}_{0.9} \mathrm{P}_{\mathrm{y}}$ exhibited the highest electrocatalytic activity towards HER due to the high crystallinity, high specific surface area and the synergistic effect of nickel and cobalt that accelerate the electron transfer process.

\section{Introduction}

Transition metals have been recently suggested as appropriate catalysts for hydrogen evolution reaction $(\mathrm{HER})^{[1]}$. The transition metal catalysts are used in alkaline media, and the alkaline water electrolysis is a competitively priced process in comparison to proton exchange membrane water electrolysis ${ }^{[2]}$. Due to the low cost, environmental benign, and high theoretical catalytic activity, Cobased materials are particularly attractive among other transition metal-based electrocatalysts for water splitting ${ }^{[3]}$. Multiple methods were used to prepare Co-based materials. For instance, $\mathrm{Co}_{4} \mathrm{~N}$ was synthesized by simple nitridation reaction and high temperature treatment with $\mathrm{Co}(\mathrm{OH}) \mathrm{F}$ nanowire $\operatorname{arrays}^{[3 c]}$. CoO nanorods (NRs) were fabricated by surface strain engineering ${ }^{[4]}$.

Metal-organic frameworks (MOFs) materials have been recently proven to be promising sacrificial template or self-template to produce electrocatalysts due to their sufficient exposed active sites, abundant organic ligands, and mesoporous structure ${ }^{[5]}$. For example, $\mathrm{Li}$ et al. ${ }^{[3 \mathrm{a}]}$ synthesized $\mathrm{Co}_{3} \mathrm{O}_{4}$ nanocrystals embedded in $\mathrm{N}$-doped mesoporous graphitic carbon layer/multiwalled carbon nanotube (MWCNT) hybrids by a facile carbonization and subsequent oxidation of MWCNT-based MOFs, which leaded to high electrochemical performance. In 2017, Cao et al. ${ }^{[3 \mathrm{~d}]}$ reported the preparation of hollow $\mathrm{CoS}_{2}$ tubular arrays by a sulfidation under thermal treatment of wire-like MOFs nanoarrays for water splitting. The 
self-agglomeration of Co-MOFs materials usually leaded to a high overpotential and decreased reaction rate.

In order to improve the efficiency and avoid self-agglomeration of Co-based materials, it is important to understand the structure-activity relationship between their electrocatalytic activities and the dispersion and valence state of the Co-based materials ${ }^{[6]}$. Different Co-based materials including sulfides, oxides, phosphides ${ }^{[7]}$, etc. show diverse electrocatalytic activity for $\mathrm{HER}^{[8]}{ }^{[9]}$.In addition, reducing the size of particles of Co-based materials, especially going to ultra-small nanoclusters or even single atoms ${ }^{[10]}$, is considered as an effective way to improve their catalytic performance. Furthermore, the introduction of a second metal component in the Co-based materials improved the resistance to corrosion in the alkaline media, and prevented the Co nanoparticles from agglomeration ${ }^{[11]}$. Several investigations have focused on MOF-derived bimetallic or multi-metallic derivatives, leading to advanced electrocatalytic performance compared with single Co-based materials ${ }^{[12]}$. For examples, He and co-workers fabricated carbon containing Ni-Co mixed metal phosphide nanoboxes (NiCoP/C) by ZIF-67 ${ }^{[12 a]}$. Liang and et al. reported the $\mathrm{Ni}_{2} \mathrm{P}-\mathrm{CoP}$ bimetallic phosphides derived from the NiCo-MOFs, which showed efficient performance for both HER and the oxygen evolution reaction (OER ${ }^{[12 c]}$. Mostly Co-MOFs under thermal decomposition conditions in the presence of a second metal were applied to fabricate new multi-metallic materials $^{[13]}$. Firstly, the Co-MOFs was prepared, then the second metal (Ni) under acidic etching or thermal decomposition was introduced resulting in mesoporous structures collapse with selfagglomerated metals. The preparation of nanosized homogenous bimetallic MOFs derivatives for HER is still a challenge ${ }^{[12 c]}$. 


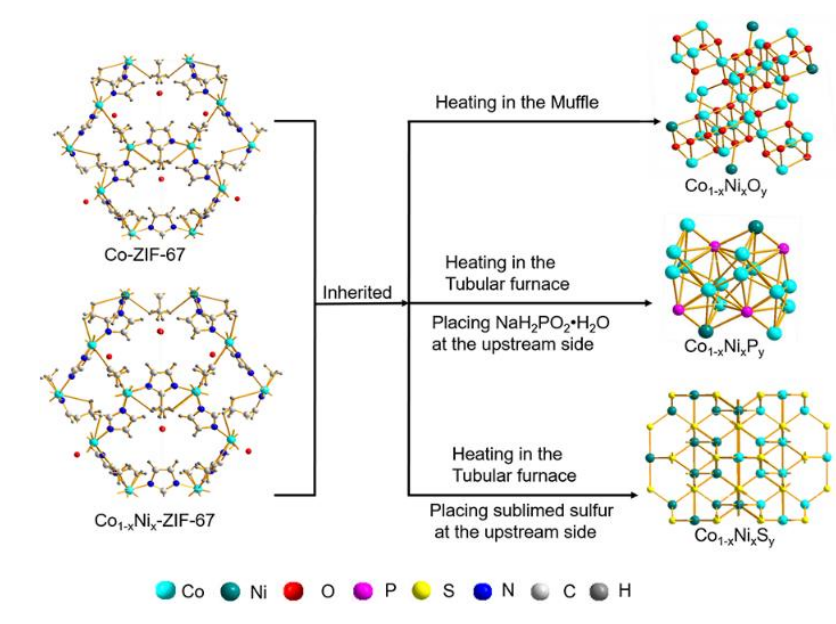

Scheme 1. Schematic diagram representing the preparation of $\mathrm{Ni}_{1-\mathrm{x}} \mathrm{Co}_{\mathrm{x}}-\mathrm{ZIFs}-67, \mathrm{Ni}_{1-\mathrm{x}} \mathrm{Co}_{\mathrm{x}} \mathrm{O}_{\mathrm{y}}, \mathrm{Ni}_{1-\mathrm{x}} \mathrm{Co}_{\mathrm{x}} \mathrm{S}_{\mathrm{y}}$ and $\mathrm{Ni}_{1-\mathrm{x}} \mathrm{Co}_{\mathrm{x}} \mathrm{P}_{\mathrm{y}}$ from $\mathrm{Ni}_{1-\mathrm{x}} \mathrm{Co}_{\mathrm{x}}-\mathrm{ZIFs}-67$

This article reports the preparation of homeotypic bimetallic catalysts $\left(\mathrm{Ni}_{1-\mathrm{x}} \mathrm{Co}_{\mathrm{x}} \mathrm{O}_{\mathrm{y}}, \mathrm{Ni}_{1-\mathrm{x}} \mathrm{Co}_{\mathrm{x}} \mathrm{S}_{\mathrm{y}}\right.$ and $\mathrm{Ni}_{1-\mathrm{x}} \mathrm{Co}_{\mathrm{x}} \mathrm{P}_{\mathrm{y}}$ ) using nanosized bimetallic precursor $\mathrm{Ni}_{1-\mathrm{x}} \mathrm{Co}_{\mathrm{x}}-\mathrm{ZIF}-67$ (Scheme 1). The uniform bimetallic $\mathrm{Ni}_{1-\mathrm{x}} \mathrm{Co}_{\mathrm{x}}$-ZIF-67 crystals $(120-135 \mathrm{~nm})$ were prepared from Co-ZIF-67 at low temperature $\left(0^{\circ} \mathrm{C}\right)(\mathrm{see}$ Experimental Section). Hence the $\mathrm{Ni}_{1-\mathrm{x}} \mathrm{Co}_{\mathrm{x}}-\mathrm{ZIF}-67$ were allowed to convert into $\mathrm{Ni}_{1-\mathrm{x}} \mathrm{Co}_{\mathrm{x}} \mathrm{O}_{\mathrm{y}}, \mathrm{Ni}_{1-\mathrm{x}} \mathrm{Co}_{\mathrm{x}} \mathrm{S}_{\mathrm{y}}$ and $\mathrm{Ni}_{1-\mathrm{x}} \mathrm{Co}_{\mathrm{x}} \mathrm{P}_{\mathrm{y}}$ materials by temperature-programmed reactions with oxygen, sublimed sulfur and sodium hypophosphite, respectively. Then, the homeotypic bi-metallic materials were deposited on glassy carbon electrode (GCE) and applied in alkaline ( $\mathrm{pH}=14)$ electrolysis for hydrogen production. The effect of the state of $\mathrm{Ni}$ and Co species on the electrocatalytic performance of the catalysts for hydrogen evolution in alkaline media was studied in detail.

\section{Results and Discussion}

\section{Characterization of $\mathrm{Ni}_{\mathrm{x}} \mathrm{Co1-x}-\mathrm{ZIF}-67, \mathrm{Ni}_{\mathrm{x}} \mathrm{Co1-x} \mathrm{O}_{y}, \mathrm{Ni}_{\mathrm{x}} \mathrm{Co1-x} \mathrm{P}_{\mathrm{y}}$, and $\mathrm{Ni}_{\mathrm{x}} \mathrm{Co1-x} \mathrm{S}_{\mathrm{y}}$ catalysts}

The crystal structure of Co-ZIF-67 and $\mathrm{Ni}_{0.1} \mathrm{Co}_{0.9}$-ZIF-67 was characterized by XRD. The XRD diffraction pattern of $\mathrm{Ni}_{0.1} \mathrm{Co}_{0.9}$-ZIF-67 is similar to the mono-metallic Co-ZIF-67 sample (Fig. 1a). Cobalt and nickel with consecutive atomic numbers easily formed homeotypic crystals. As shown in Fig. 
$\mathrm{S} 1 \mathrm{a}$, the XRD patterns of samples $\mathrm{Ni}_{\mathrm{x}} \mathrm{Co}_{1-\mathrm{x}}-\mathrm{ZIF}-67$ with different $\mathrm{Ni} / \mathrm{Co}$ ratios contain broad peaks, but their positions are identical with the simulated pattern of Co-ZIF- $67^{[14]}$. No impurity was found in samples $\mathrm{Ni}_{\mathrm{x}} \mathrm{Co}_{1-\mathrm{x}}$-ZIF-67, implying that $\mathrm{Ni}^{2+}$ ions are effectively incorporated into the Co-ZIF-67 ${ }^{[15]}$. The intensity of the peaks for $\mathrm{Ni}_{\mathrm{x}} \mathrm{Co}_{1-\mathrm{x}}$-ZIF-67 (Fig.S1a) decreased with an increase of nickel content, which is related to the changes of charge distribution and electrostatic fields as a result of the existence of both nickel and cobalt within the framework ${ }^{[16]}$. While the XRD patterns of samples $\mathrm{Co}_{3} \mathrm{O}_{4}$ and $\mathrm{Ni}_{0.2} \mathrm{Co}_{0.8} \mathrm{O}_{\mathrm{y}}($ Fig. 1b) contain peaks at $31.3^{\circ}$ and $36.8^{\circ} 2$ Theta corresponding to (100) and (101) planes of $\mathrm{Co}_{3} \mathrm{O}_{4}{ }^{[17]}$, and a peak at $43.0^{\circ}$ corresponding to (200) plane of $\mathrm{NiO}^{[11 \mathrm{c}, 18]}$. This result indicates that the $\mathrm{Ni}_{\mathrm{x}} \mathrm{Co}_{1-\mathrm{x}}-\mathrm{ZIF}-67$ is fully transformed to $\mathrm{Ni}_{0.2} \mathrm{Co}_{0.8} \mathrm{O}_{\mathrm{y}}$. The XRD patters of samples $\mathrm{CoP}$ and $\mathrm{Ni}_{0.1} \mathrm{Co}_{0.9} \mathrm{P}_{\mathrm{y}}$ are shown in Fig. 1c. The Bragg peaks at 31.6, 36.6, 46.3 and $48.7^{\circ} 2$ Theta correspond to the (011), (111), (112) and (211) planes of $\mathrm{CoP}^{[3 \mathrm{~b}, 12 \mathrm{a}, 12 \mathrm{c}]}$, and the peak at $41.0^{\circ} 2$ Theta corresponds to (321) plane of $\mathrm{Ni}_{3} \mathrm{P}^{[12 \mathrm{~b}, 19]}$, which confirm the transformation from $\mathrm{Ni}_{\mathrm{x}} \mathrm{Co}_{1-\mathrm{x}} \mathrm{ZIF}-67$ to $\mathrm{CoP}$ and $\mathrm{N}_{\mathrm{i} 0.1} \mathrm{Co}_{0.9} \mathrm{P}_{\mathrm{y}}$. The nanosized bimetallic atomic arrangement in the $\mathrm{Ni}_{\mathrm{x}} \mathrm{Co}_{1-\mathrm{x}}-\mathrm{ZIF}-67$ is demonstrated as well (Fig. S1c). The XRD patterns of $\mathrm{Cog}_{9} \mathrm{~S}_{8}$ and $\mathrm{Ni}_{0.5} \mathrm{Co}_{0.5} \mathrm{~S}_{\mathrm{y}}$ samples are depicted in Fig. 1d. The peaks at 15.3, 29.8, 31.2 and $47.5^{\circ} 2$ Theta correspond to (111), (311), (222) and (511) planes of $\mathrm{Cog}_{9} \mathrm{~S}_{8}{ }^{[20]}$, and the peak at $44.4^{\circ}$ is related to the (102) plane of $\mathrm{NiS}{ }^{[11 \mathrm{a}]}$, indicating the formation of $\mathrm{Co}_{9} \mathrm{~S}_{8}$ and $\mathrm{Ni}_{0.5} \mathrm{Co}_{0.5} \mathrm{~S}_{\mathrm{y}}$. 

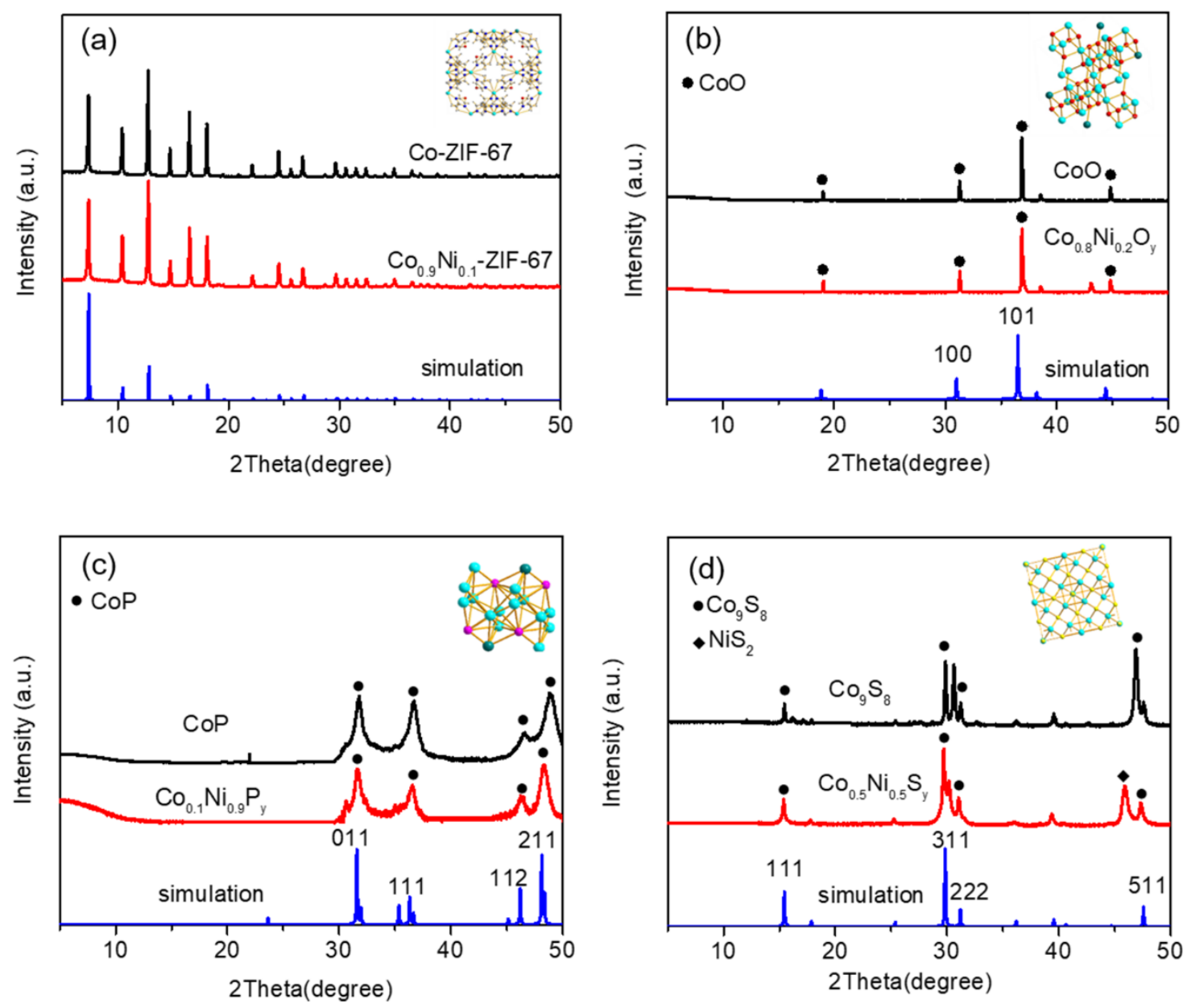

Figure 1. XRD patterns of Co-ZIF-67 and $\mathrm{Ni}_{0.1} \mathrm{Co}_{0.9}-\mathrm{ZIF}-67$ (a), $\mathrm{Co}_{3} \mathrm{O}_{4}$ and $\mathrm{Ni}_{0.2} \mathrm{Co}_{0.8} \mathrm{O}_{\mathrm{y}}(\mathrm{b}), \mathrm{CoP}$ and $\mathrm{Ni}_{0.1} \mathrm{Co}_{0.9} \mathrm{P}_{\mathrm{y}}(\mathrm{c})$ and $\mathrm{Co}_{9} \mathrm{~S}_{8}$ and $\mathrm{Ni}_{0.5} \mathrm{Co}_{0.5} \mathrm{~S}_{\mathrm{y}}(\mathrm{d})$.
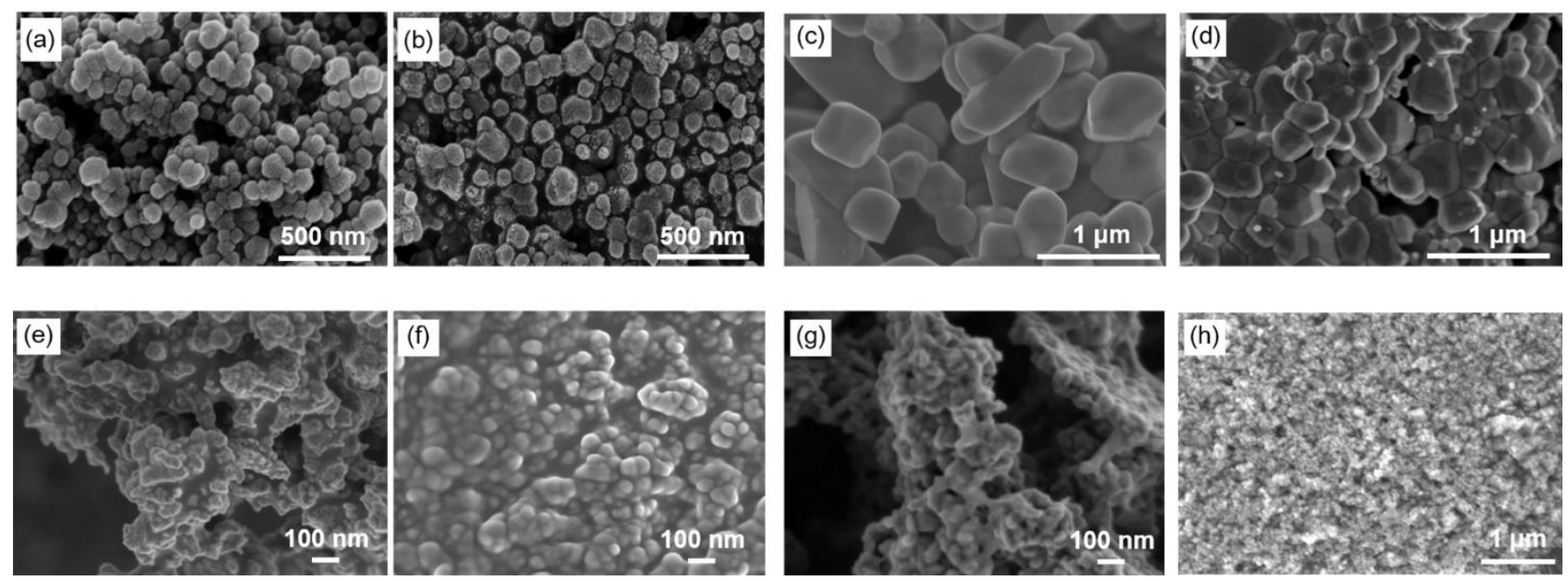

Figure 2. SEM images of Co-ZIF-67 (a), $\mathrm{Ni}_{0.1} \mathrm{Co}_{0.9}-\mathrm{ZIF}-67$ (b), $\mathrm{Co}_{3} \mathrm{O}_{4}$ (c), $\mathrm{Ni}_{0.2} \mathrm{Co}_{0.8} \mathrm{O}_{\mathrm{y}}(\mathrm{d}), \mathrm{CoP}$ (e), $\mathrm{Ni}_{0.1} \mathrm{Co}_{0.9} \mathrm{P}_{\mathrm{y}}(\mathrm{f}), \mathrm{Co}_{9} \mathrm{~S}_{8}(\mathrm{~g})$ and $\mathrm{Ni}_{0.5} \mathrm{Co}_{0.5} \mathrm{~S}_{\mathrm{y}}(\mathrm{h})$ 
The SEM images for all samples (Co-ZIF-67 and $\mathrm{Ni}_{0.1} \mathrm{Co}_{0.9}-\mathrm{ZIF}-6, \mathrm{Co}_{3} \mathrm{O}_{4}$ and $\mathrm{Ni}_{0.2} \mathrm{Co}_{0.8} \mathrm{O}_{\mathrm{y}}, \mathrm{CoP}$, $\mathrm{Ni}_{0.1} \mathrm{Co}_{0.9} \mathrm{P}_{\mathrm{y}}, \mathrm{Co}_{9} \mathrm{~S}_{8}$ and $\mathrm{Ni}_{0.5} \mathrm{Co}_{0.5} \mathrm{~S}_{\mathrm{y}}$ ) are presented in Fig. 2. The Co-ZIF-67 crystals (Fig. 2a) have a diameter of $86 \mathrm{~nm}$ and nearly spheroidal shape. As shown in Fig. $2 \mathrm{~b}$, the $\mathrm{Ni}_{0.1} \mathrm{Co}_{0.9}$-ZIF-67 crystals have similar morphology and a size of $135 \mathrm{~nm}$. After oxidation, the derived $\mathrm{Co}_{3} \mathrm{O}_{4}$ crystals (Fig. 2c) have dodecahedral shape with an average size of $300 \mathrm{~nm}$, while the $\mathrm{Ni}_{0.2} \mathrm{Co}_{0.8} \mathrm{O}_{\mathrm{y}}$ crystals have an average size of $206 \mathrm{~nm}$ (Fig. 2d). The crystal size of the samples increases about twice after oxidation of the $\mathrm{Ni}_{\mathrm{x}} \mathrm{Co}_{1}$ x-ZIF-67, indicating that two or three $\mathrm{Ni}_{\mathrm{x}} \mathrm{Co}_{1-\mathrm{x}}$-ZIF-67 nanoparticles coalesce into one $\mathrm{Ni}_{\mathrm{x}} \mathrm{Co}_{1-\mathrm{x}} \mathrm{O}_{\mathrm{y}}$ particle. In the case of phosphides, the derived $\mathrm{CoP}$ showed an average size of $34 \mathrm{~nm}$ (Fig. 2e), and the $\mathrm{N}_{\mathrm{i} 0.1} \mathrm{Co}_{0.9} \mathrm{P}_{\mathrm{y}}$ crystals have an average size of $23 \mathrm{~nm}$ (Fig. 2f), which are smaller than the $\mathrm{Ni}_{\mathrm{x}} \mathrm{Co}_{1-\mathrm{x}}-\mathrm{ZIF}-67$. The derived $\mathrm{Co}_{9} \mathrm{~S}_{8}$ crystals have an average size of $15 \mathrm{~nm}$ (Fig. $2 \mathrm{~g}$ ), while the $\mathrm{Ni}_{0.5} \mathrm{Co}_{0.5} \mathrm{~S}_{\mathrm{y}}$ has a size of $12 \mathrm{~nm}$ (Fig. 2h), which are considerably smaller than the $\mathrm{Ni}_{\mathrm{x}} \mathrm{Co}_{1-\mathrm{x}}-\mathrm{ZIF}-67$ crystals. The energy dispersive X-ray (EDS) elemental mapping and the elements proportion presented in Fig. S3 also confirm the uniform distribution of all elements in the Co-ZIF-67 (a) (Co ,C ,N ,O), Nio.1 Co.9-ZIF-67 (b) (Co, Ni), $\mathrm{Co}_{3} \mathrm{O}_{4}$ (c) (Co, O), $\mathrm{Ni}_{0.2} \mathrm{Co}_{0.8} \mathrm{O}_{\mathrm{y}}(\mathrm{d})(\mathrm{Ni}, \mathrm{Co}, \mathrm{O}), \mathrm{CoP}(\mathrm{e})(\mathrm{Co}, \mathrm{P}), \mathrm{Ni}_{0.1} \mathrm{Co}_{0.9} \mathrm{P}_{\mathrm{y}}(\mathrm{f})(\mathrm{Ni}, \mathrm{Co}, \mathrm{P}), \mathrm{Co}_{9} \mathrm{~S}_{8}(\mathrm{~g})(\mathrm{Co}, \mathrm{S})$ and $\mathrm{Ni}_{0.5} \mathrm{Co}_{0.5} \mathrm{~S}_{\mathrm{y}}$ (h) $(\mathrm{Ni}, \mathrm{Co}, \mathrm{S})$. Additionally, the chemical composition of the materials was characterized by ICP-AES (Table S1). The content of metals (Co \& Ni) in the oxide, sulfide and phosphide is much higher than in the Co-ZIF-67 and $\mathrm{Ni}_{0.1} \mathrm{Co}_{0.9}$-ZIF-67 samples, indicating that most of the $\mathrm{C}, \mathrm{N}$ and $\mathrm{H}$ elements were pyrolyzed after the high-temperature treatment and the target products were prepared successfully.The transmission electron microscopy (TEM) images for all samples (Co-ZIF-67 and $\mathrm{Ni}_{0.1} \mathrm{Co}_{0.9}-\mathrm{ZIF}-6, \mathrm{Co}_{3} \mathrm{O}_{4}$ and $\mathrm{Ni}_{0.2} \mathrm{Co}_{0.8} \mathrm{O}_{\mathrm{y}}, \mathrm{CoP}, \mathrm{Ni}_{0.1} \mathrm{Co}_{0.9} \mathrm{P}_{\mathrm{y}}, \mathrm{Co}_{9} \mathrm{~S}_{8}$ and $\left.\mathrm{Ni}_{0.5} \mathrm{Co}_{0.5} \mathrm{~S}_{\mathrm{y}}\right)$ are shown in Fig. S2. The TEM results are consistent with SEM. The $\mathrm{Ni}_{0.1} \mathrm{Co}_{0.9}$-ZIF sample contains the same Co lattice with a Co-ZIF-67(111) interlayer spacing of $0.20 \mathrm{~nm}$ (Fig. 2a,b). The lattice fringes of $\mathrm{Co}_{3} \mathrm{O}_{4}$ and $\mathrm{Ni}_{0.2} \mathrm{Co}_{0.8} \mathrm{O}_{\mathrm{y}}$ display interplanar spacings of $0.24 \mathrm{~nm}$, which match well with the (311) planes of the $\mathrm{Co}_{3} \mathrm{O}_{4}$ (Fig. 3c,d). TEM images reveal that the $\mathrm{Ni}_{0.1} \mathrm{Co}_{0.9} \mathrm{P}_{\mathrm{y}}$ retained small size with rough surface (Fig. S2 e,f). Moreover, the resolved interplanar distances of 0.09 and $0.12 \mathrm{~nm}$ from the HRTEM image can be ascribed to the (211) and (111) planes of CoP, respectively (Fig. S2 e,f insert image). $\mathrm{Ni}_{0.1} \mathrm{Co}_{0.9} \mathrm{P}_{\mathrm{y}}$ and $\mathrm{Ni}_{0.5} \mathrm{Co}_{0.5} \mathrm{~S}_{\mathrm{y}}$ crystals with the 
similar sizes are revealed by both TEM and SEM.The carbon cladding outside the metal particles (Fig. S2g), the carbon layer of the entire nanoparticle are evenly formed and thinner (Fig. S2h); the carboncoated metal particles can be clearly seen. The interplanar distances of 0.14 and $0.15 \mathrm{~nm}$ resolved from the HRTEM image are ascribed to the (311) and (222) planes of $\mathrm{Co}_{9} \mathrm{~S}_{8}$, respectively (Fig. S2 g,h insert image).
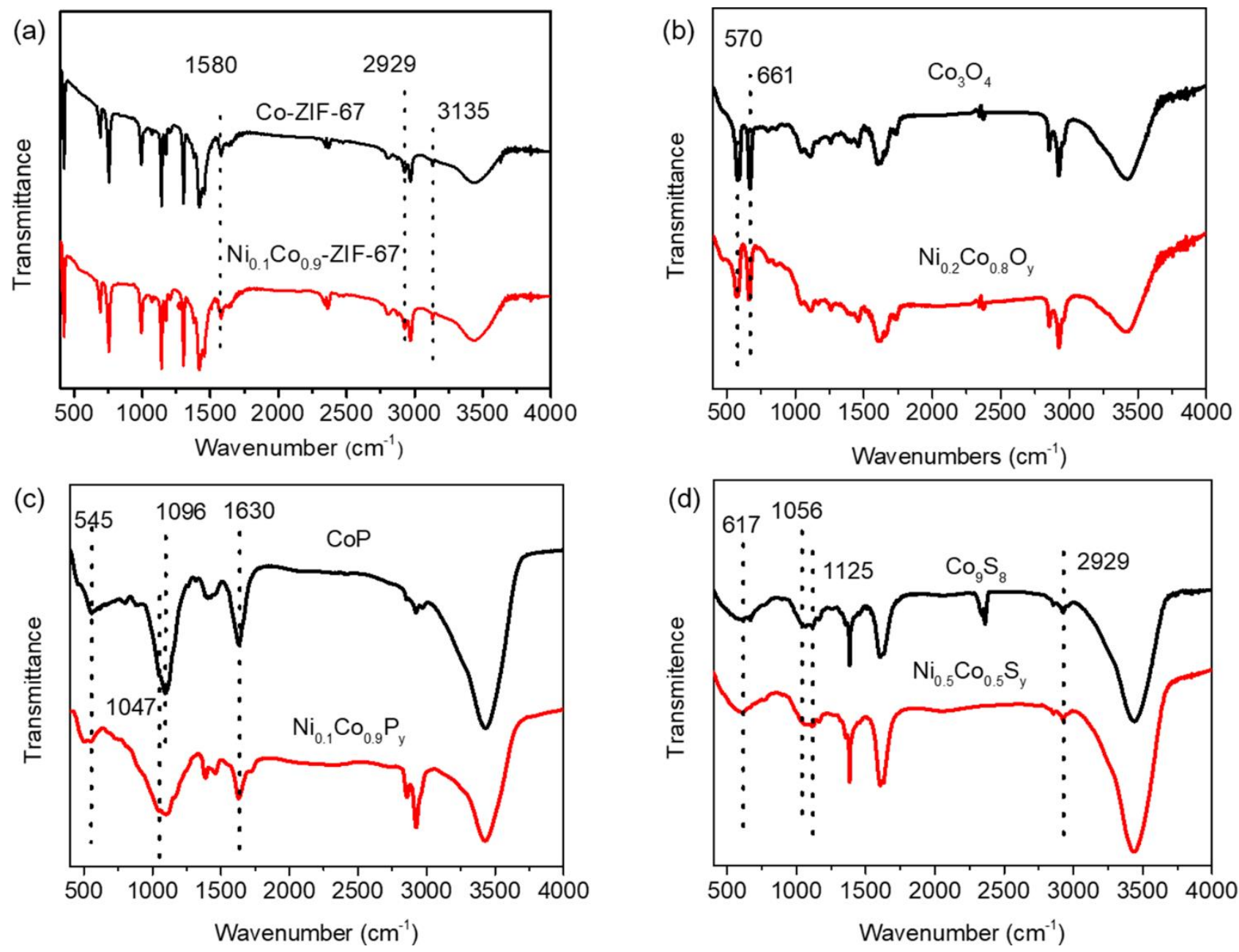

Figure 3. FT-IR spectra of Co-ZIF-67 and $\mathrm{Ni}_{0.1} \mathrm{Co}_{0.9}-\mathrm{ZIF}-67$ (a), $\mathrm{Co}_{3} \mathrm{O}_{4}$ and $\mathrm{Ni}_{0.2} \mathrm{Co}_{0.8} \mathrm{O}_{\mathrm{y}}(\mathrm{b}), \mathrm{CoP}$ and $\mathrm{Ni}_{0.1} \mathrm{Co}_{0.9} \mathrm{P}_{\mathrm{y}}(\mathrm{c}), \mathrm{Co}_{9} \mathrm{~S}_{8}$ and $\mathrm{Ni}_{0.5} \mathrm{Co}_{0.5} \mathrm{~S}_{\mathrm{y}}(\mathrm{d})$

The $\mathrm{N}_{2}$ adsorption-desorption study was applied to reveal the porous nature of the samples (Figure S4). The specific surface area of samples Co-ZIF-67 and $\mathrm{Ni}_{0.1} \mathrm{Co}_{0.9}-\mathrm{ZIF}-67$ is $1402.4 \mathrm{~m}^{2} \mathrm{~g}^{-1}$ and 1242.8 $\mathrm{m}^{2} \mathrm{~g}^{-1}$, respectively. The isotherm of Co-ZIF-67 and $\mathrm{Ni}_{0.1} \mathrm{Co}_{0.9}-\mathrm{ZIF}-67$ are identified as type I, which is characteristic of microporous materials. The corresponding Density Functional Theory (DFT) results and 
pore size distribution curve further indicates that Co-ZIF-67 contains the micropores. The BET specific surface area for sample $\mathrm{Co}_{3} \mathrm{O}_{4}$, is $2.2 \mathrm{~m}^{2} \mathrm{~g}^{-1}$, while for $\mathrm{Ni}_{0.2} \mathrm{Co}_{0.8} \mathrm{O}_{\mathrm{y}}$ is $3.2 \mathrm{~m}^{2} \mathrm{~g}^{-1}$. The isotherms of $\mathrm{CoP}$ and $\mathrm{Ni}_{0.1} \mathrm{Co}_{0.9} \mathrm{P}_{\mathrm{y}}$ are identified as type IV characteristic of mesoporous materials. CoP had a BET surface area of $19.4 \mathrm{~m}^{2} \mathrm{~g}^{-1}$, while for $\mathrm{Ni}_{0.1} \mathrm{Co}_{0.9} \mathrm{P}_{\mathrm{y}}$ is $12.3 \mathrm{~m}^{2} \mathrm{~g}^{-1}$ (Fig. S5 a, b). The specific surface area of $\mathrm{Co}_{9} \mathrm{~S}_{8}$ is $105.1 \mathrm{~m}^{2} \mathrm{~g}^{-1}$ and for $\mathrm{Ni}_{0.5} \mathrm{Co}_{0.5} \mathrm{~S}_{\mathrm{y}}$ is $107.5 \mathrm{~m}^{2} \mathrm{~g}^{-1}$ (Figure S5 c, d and Table S2.)The above results suggest that for the oxide and sulfide, the bimetallic catalysts with larger specific surface area would provide abundant catalytic active sites and facilitates the transport of electron and active species during the catalysis process. While only the phosphide are characteristic of mesoporous materials, we assume that the mesoporous structure is beneficial for charge and mass transport for electrocatalysis.

The FT-IR spectra of Co-ZIF-67 and $\mathrm{Ni}_{0.1} \mathrm{Co}_{0.9}$-ZIF-67 are shown in Fig. 3a.The IR bands are primarily attributed to the ligand 2-Methylimidazole (2-MIM). The peaks in the range of $600-1500 \mathrm{~cm}^{-1}$ correspond to the stretching and bending modes of the imidazole rings, whereas the band at $1580 \mathrm{~cm}^{-1}$ is attributed to the C-N stretching mode of 2-MIM. Additionally, the bands at 2929 and $3135 \mathrm{~cm}^{-1}$ correspond to the $\mathrm{C}-\mathrm{H}$ stretching mode of the aromatic ring and the aliphatic chain of the 2-MIM, respectively ${ }^{[21]}$. This result reveals that the bi-metallic $\mathrm{Ni}_{0.1} \mathrm{Co}_{0.9}-\mathrm{ZIF}-67$ crystals have been successfully prepared. 

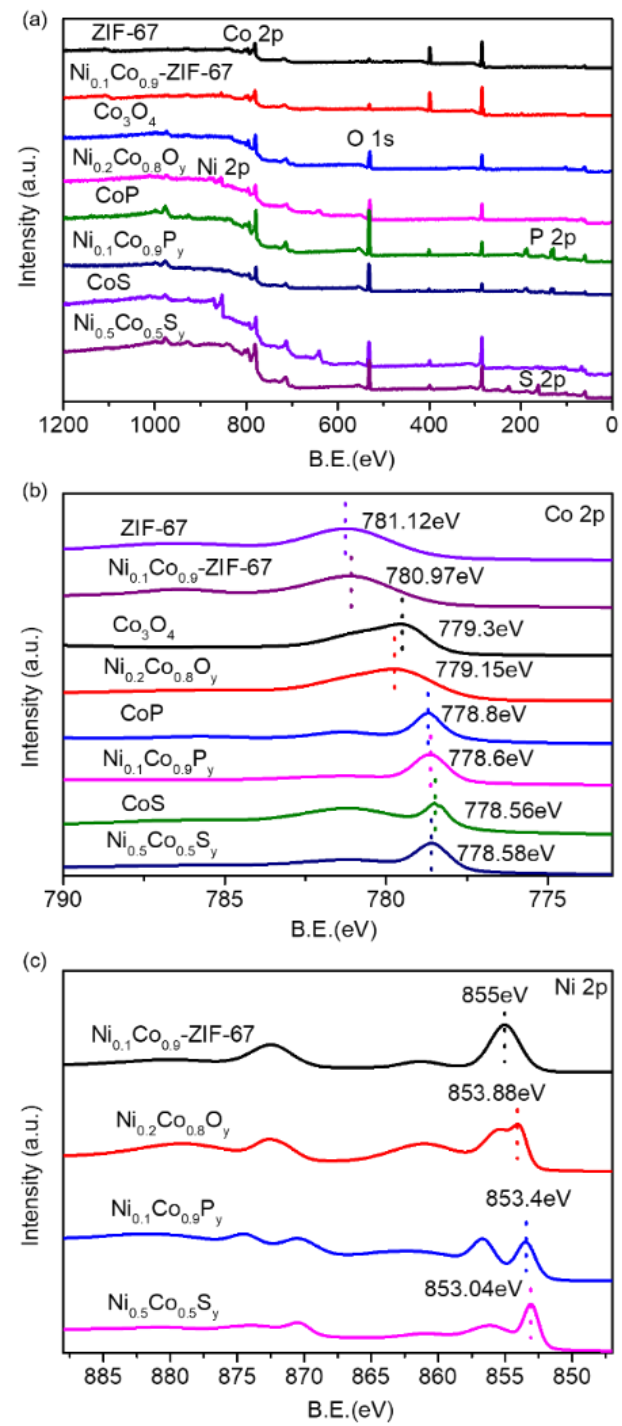

Figure 4. XPS spectra of Co-ZIF-67, $\mathrm{Ni}_{0.1} \mathrm{Co}_{0.9}-\mathrm{ZIF}-67, \mathrm{Co}_{3} \mathrm{O}_{4}, \mathrm{Ni}_{0.2} \mathrm{Co}_{0.8} \mathrm{O}_{\mathrm{y}}, \mathrm{CoP}, \mathrm{Ni}_{0.1} \mathrm{Co}_{0 .} \mathrm{P}_{\mathrm{y}}$, $\mathrm{Co}_{9} \mathrm{~S}_{8}$ and $\mathrm{Ni}_{0.5} \mathrm{Co}_{0.5} \mathrm{~S}_{\mathrm{y}}$ catalysts in the range $100-1200 \mathrm{eV}$ (a), 775-790 eV Co $2 \mathrm{p}(\mathrm{b})$, and 850-890 eV Ni $2 p(c)$

While several peaks in the range of $600 \sim 1500 \mathrm{~cm}^{-1}$ are not present in the spectra of $\mathrm{Co}_{3} \mathrm{O}_{4}$ and $\mathrm{Ni}_{0.2} \mathrm{Co}_{0.8} \mathrm{O}_{\mathrm{y}}$, and the stretching mode of $\mathrm{C}-\mathrm{N}$ bonding and the aliphatic chain of the 2-MIM at $1580 \mathrm{~cm}^{-}$ ${ }^{1}$ and $3135 \mathrm{~cm}^{-1}$, respectively become obscured (Fig. 4b). The C-H stretching mode of the aromatic ring at $2929 \mathrm{~cm}^{-1}$ is present. The peaks at $661 \mathrm{~cm}^{-1}$ and $570 \mathrm{~cm}^{-1}$ corresponding to the Co-O vibration ${ }^{[22]}$ confirm that the ZIF-67 structure collapsed and Co is oxidized into $\mathrm{Co}_{3} \mathrm{O}_{4}$.

The FT-IR analysis verifies the presence of $\mathrm{P}-\mathrm{O}$ bands in the spectra of $\mathrm{CoP}$ and $\mathrm{Ni}_{0.1} \mathrm{Co}_{0.9} \mathrm{P}_{\mathrm{y}}$ as 
shown in Figure 3c. Several bands in the region of $1150-1000 \mathrm{~cm}^{-1}$ are assigned to the P-O vibrations of the $\mathrm{PO}_{4}$ group ${ }^{[23]}$. While the signals associated with the $\mathrm{C}-\mathrm{N}$ stretching and the aliphatic chain of 2-MIM $\left(1580 \mathrm{~cm}^{-1}\right.$ and $\left.3135 \mathrm{~cm}^{-1}\right)$ are present in the spectra of $\mathrm{Co}_{9} \mathrm{~S}_{8}$ and $\mathrm{Ni}_{0.5} \mathrm{Co}_{0.5} \mathrm{~S}_{\mathrm{y}}$ (Fig. 3d) indicating that ZIF-67 structure almost collapsed after sulfuration. The new band at $617 \mathrm{~cm}^{-1}$ belongs to the Co-S bending vibration of the $\mathrm{Cog}_{9} \mathrm{~S}_{8}{ }^{[20 \mathrm{~b}]}$. The peak at $1125 \mathrm{~cm}^{-1}$ is assigned to the $\mathrm{S}-\mathrm{O}$ bending vibration ${ }^{[24]}$, indicating that $\mathrm{Co}$ is sulfured into $\mathrm{Co}_{9} \mathrm{~S}_{8}$. The IR study confirmed that $\mathrm{Ni}_{\mathrm{x}} \mathrm{Co}_{1-\mathrm{x}} \mathrm{O}_{\mathrm{y}}, \mathrm{Ni}_{\mathrm{x}} \mathrm{Co}_{1-\mathrm{x}} \mathrm{P}_{\mathrm{y}}$ and $\mathrm{Ni}_{\mathrm{x}} \mathrm{Co}_{1-\mathrm{x}} \mathrm{S}_{\mathrm{y}}$ catalysts have been successfully synthesized.

The XPS spectra of all catalysts are shown in Fig. 4. The standard binding energy of the main peak of cobalt species $\left(\mathrm{Co} 2 \mathrm{p}_{3 / 2}\right)$ at $777.9 \mathrm{eV}$ is present in all as-synthesized catalysts. While the $\mathrm{Co} 2 \mathrm{p}_{3 / 2}$ core level region contains a main peak at $780.97 \mathrm{eV}\left(\mathrm{Ni}_{0.1} \mathrm{Co}_{0.9}-\mathrm{ZIF}-67\right), 779.15 \mathrm{eV}\left(\mathrm{Ni}_{0.2} \mathrm{Co}_{0.8} \mathrm{O}_{\mathrm{y}}\right), 778.6 \mathrm{eV}$ $\left(\mathrm{Ni}_{0.1} \mathrm{Co}_{0.9} \mathrm{P}_{\mathrm{y}}\right)$ and $778.56 \mathrm{eV}\left(\mathrm{Ni}_{0.5} \mathrm{Co}_{0.5} \mathrm{~S}_{\mathrm{y}}\right)$, indicating the differences of the energy shift in the Co $2 \mathrm{p}$ spectra (Fig. 4b). The as-prepared materials show higher binding energy in the $\mathrm{Ni} 2 \mathrm{p}_{3 / 2}$ region compared with nickel species $(852.3 \mathrm{eV})$, for instance, $855 \mathrm{eV}$ for $\mathrm{Ni}_{0.1} \mathrm{Co}_{0.9}-\mathrm{ZIF}-67,853.88 \mathrm{eV}$ for $\mathrm{Ni}_{0.2} \mathrm{Co}_{0.8} \mathrm{O}_{\mathrm{y}}$, 853.4eV for $\mathrm{Ni}_{0.1} \mathrm{Co}_{0.9} \mathrm{P}_{\mathrm{y}}$ and $853 \mathrm{eV}$ for $\mathrm{Ni}_{0.5} \mathrm{Co}_{0.5} \mathrm{~S}_{\mathrm{y}}(\mathrm{Fig} .4 \mathrm{c})$.

The XPS spectra of $\mathrm{Ni}_{\mathrm{x}} \mathrm{Co}_{1-\mathrm{x}} \mathrm{O}_{\mathrm{y}}, \mathrm{Ni}_{\mathrm{x}} \mathrm{Co}_{1-\mathrm{x}} \mathrm{P}_{\mathrm{y}}$, and $\mathrm{Ni}_{\mathrm{x}} \mathrm{Co}_{1-\mathrm{x}} \mathrm{S}_{\mathrm{y}}$ catalysts are shown in the SI (Figs. S5$\mathrm{S} 7$ ). The $\mathrm{Ni}_{0.1} \mathrm{Co}_{0.9} \mathrm{P}_{\mathrm{y}}$ (Fig. S6), shows low binding energy (Co $2 \mathrm{p}_{1 / 2}$ and $\mathrm{Ni} 2 \mathrm{p}_{1 / 2}$ ) compared to metallic $\mathrm{Ni}, \mathrm{Co}$, and $\mathrm{P}$. The binding energies of $\mathrm{Ni} 2 \mathrm{p}$ and $\mathrm{Co} 2 \mathrm{p}$ exhibit positive shifts while $\mathrm{P} 2 \mathrm{p}$ is negatively shifted which is mainly due to the partial electron transfer from $\mathrm{Ni}$ and $\mathrm{Co}$ to $\mathrm{P}$.

The positive metallic ( $\mathrm{Ni}$ and $\mathrm{Co}$ ) and negative $\mathrm{P}$ centers can play a role of hydride-acceptor and proton-acceptor sites, respectively, during the electrocatalytic process ${ }^{[19,25]}$. Therefore, the positively charged $\mathrm{Co}$ and $\mathrm{Ni}$ and the negatively charged $\mathrm{O}, \mathrm{P}$ and $\mathrm{S}$ centers could act as hydride-acceptor and proton-acceptor, respectively. The acceptor could promote the formation of cobalt hydride, which could facilitate the following $\mathrm{H}_{2}$ evolution by electrochemical desorption [3b, 9a, 19, 25b, 26].

Electrocatalytic performance of $\mathrm{Ni}_{\mathrm{x}} \mathrm{Co1-x}-\mathrm{ZIF}-67, \mathrm{Ni}_{\mathrm{x}} \mathrm{Co1-x} \mathrm{O}_{\mathrm{y}}, \mathrm{Ni}_{\mathrm{x}} \mathrm{Co1}_{-\mathrm{x}} \mathrm{P}_{\mathrm{y}}$, and $\mathrm{Ni}_{\mathrm{x}} \mathrm{Co1}_{-\mathrm{x}} \mathrm{S}_{\mathrm{y}}$ for hydrogen evolution reaction (HER) 
The electrocatalytic property of the nickel-cobalt based catalysts towards HER is evaluated. Fig. S5 shows LSV curves in alkaline media $(\mathrm{pH}=14 \pm 0.5)$ for $\mathrm{Ni}_{\mathrm{x}} \mathrm{Co}_{1-\mathrm{x}} \mathrm{ZIF}(\mathrm{a}), \mathrm{Ni}_{\mathrm{x}} \mathrm{Co}_{1-\mathrm{x}} \mathrm{O}_{\mathrm{y}}(\mathrm{b}), \mathrm{Ni}_{\mathrm{x}} \mathrm{Co}_{1-\mathrm{x}} \mathrm{P}_{\mathrm{y}}$ (c), $\mathrm{Ni}_{\mathrm{x}} \mathrm{Co}_{1-\mathrm{x}} \mathrm{S}_{\mathrm{y}}(\mathrm{d})$ at a scan rate of $10 \mathrm{mV} \mathrm{s}^{-1}$, respectively. It was found that at a current density of 10 $\mathrm{mA} \mathrm{cm}{ }^{-2}$, the catalysis showed overpotential in the following order, phosphide $<$ oxide $<$ sulfide $<$ ZIF-67 in both mono-metallic and bi-metallic derivatives with specific metal ratio: $\mathrm{CoP}<\mathrm{Co}_{3} \mathrm{O}_{4}<\mathrm{Co}_{9} \mathrm{~S}_{8}<\mathrm{ZIF}-$ 67 and $\mathrm{Ni}_{0.1} \mathrm{Co}_{0.9} \mathrm{P}_{\mathrm{y}}<\mathrm{Ni}_{0.2} \mathrm{Co}_{0.8} \mathrm{O}_{\mathrm{y}}<\mathrm{Ni}_{0.5} \mathrm{Co}_{0.5} \mathrm{~S}_{\mathrm{y}}<\mathrm{Ni}_{0.1} \mathrm{Co}_{0.9}-\mathrm{ZIF}-67$. The comparison of alkaline HER activities of as-prepared catalysts with the same ratio in the precursor are listed in the supporting information (Table S3). Obviously, the phosphide wuith the metal ratio $\mathrm{Co}: \mathrm{Ni}=10: 0,9: 1$, and 7:3 showed the lowest overpotential at current density of $10 \mathrm{~mA} \mathrm{~cm}$, while the others (samples $\mathrm{Ni}_{0.2} \mathrm{Co}_{0.8} \mathrm{O}_{\mathrm{y}}$, $\mathrm{Ni}_{0.4} \mathrm{Co}_{0.6} \mathrm{O}_{\mathrm{y}}$ and $\mathrm{Ni}_{0.5} \mathrm{Co}_{0.5} \mathrm{~S}_{\mathrm{y}}$ ) show the lowest overpotential. The phosphide performed superior in the high Co: Ni ratio, while the oxide and sulfide showed good performance in the middle ratio, indicating the optimum synergistic effect of $\mathrm{Ni}$ and $\mathrm{Co}$ in samples $\mathrm{Ni}_{\mathrm{x}} \mathrm{Co}_{1-\mathrm{x}} \mathrm{O}_{\mathrm{y}}, \mathrm{Ni}_{\mathrm{x}} \mathrm{Co}_{1-\mathrm{x}} \mathrm{P}_{\mathrm{y}}$ and $\mathrm{Ni}_{\mathrm{x}} \mathrm{Co}_{1-\mathrm{x}} \mathrm{S}_{\mathrm{y}}$. The LSV, Tafel plot and Electrochemical Impedance Spectroscopy (EIS) results are shown in the Figure. 5. The Fig. 5a shows linear sweep voltammetry (LSV) curves for $\mathrm{Ni}_{0.1} \mathrm{Co}_{0.9}-\mathrm{ZIF}-67, \mathrm{Ni}_{0.2} \mathrm{Co}_{0.8} \mathrm{O}_{\mathrm{y}}, \mathrm{Ni}_{0.5} \mathrm{Co}_{0.5} \mathrm{~S}_{\mathrm{y}}$, and $\mathrm{Ni}_{0.1} \mathrm{Co}_{0.9} \mathrm{P}_{\mathrm{y}}$ catalysts in alkaline media $(\mathrm{pH}=14 \pm 0.5)$ in comparison with bare glassy carbon electrode (GCE) and commercial $\mathrm{Pt} / \mathrm{C}$ catalyst. The $\mathrm{Ni}_{0.1} \mathrm{Co}_{0.9} \mathrm{P}_{\mathrm{y}}$ is the most active for alkaline HER with a low overpotential of $160 \mathrm{mV}$ to deliver $10 \mathrm{~mA} \mathrm{~cm}^{-2}$. As shown in Table $\mathrm{S} 4$, (supporting information), compared with other as-prepared catalysts and previously reported Co-based catalysts, clearly the $\mathrm{Ni}_{\mathrm{x}} \mathrm{Co}_{1}$ ${ }_{x} \mathrm{P}_{\mathrm{y}}$ catalysts have relatively lower overpotentials at the current densities of both 10 and $20 \mathrm{~mA} \mathrm{~cm}^{-2}$. Moreover, the $\mathrm{Ni}_{0.1} \mathrm{Co}_{0.9} \mathrm{P}_{\mathrm{y}}$ has the lowest Tafel slope of $100 \mathrm{mV} \mathrm{dec}{ }^{-1}$, being smaller than that of $\mathrm{Ni}_{0.1} \mathrm{Co}_{0.9}$-ZIF-67 $\left(109.11 \mathrm{mV} \mathrm{dec}^{-1}\right), \mathrm{Ni}_{0.2} \mathrm{Co}_{0.8} \mathrm{O}_{\mathrm{y}}\left(129.28 \mathrm{mV} \mathrm{dec}^{-1}\right)$ and $\mathrm{Ni}_{0.5} \mathrm{Co}_{0.5} \mathrm{~S}_{\mathrm{y}}\left(279.43 \mathrm{mV} \mathrm{dec}^{-1}\right)$ catalysts (Fig. 5b). To evaluate the catalytic activities, the electrochemical impedance spectroscopy analysis for $\mathrm{Ni}_{0.1} \mathrm{Co}_{0.9} \mathrm{P}_{\mathrm{y}}$ catalyst under the same operating conditions was conducted. For $\mathrm{Ni}_{0.1} \mathrm{Co}_{0.9}-\mathrm{ZIF}-$ 67, $\mathrm{Ni}_{0.2} \mathrm{Co}_{0.8} \mathrm{O}_{\mathrm{y}}, \mathrm{Ni}_{0.5} \mathrm{Co}_{0.5} \mathrm{~S}_{\mathrm{y}}$, and $\mathrm{Ni}_{0.1} \mathrm{Co}_{0.9} \mathrm{P}_{\mathrm{y}}$ catalysts, low charge transfer resistances of 24.8, 21.0, 49.8, and 10.2 $\Omega$, respectively are measured (Fig. 5c). In the equivalent circuit, Rs is related to the electrical transport property of a catalyst. The charge transfer resistance (Rct) is associated with the 
catalytic kinetics at the catalyst/electrolyte interface, small Rct values contribute to faster charge transfer. The sharply decreased diameter of $\mathrm{Ni}_{0.1} \mathrm{Co}_{0.9} \mathrm{P}_{\mathrm{y}}$ in the Nyquist plots of Fig. 5c suggests a much faster electron-transfer kinetics. The $\mathrm{Ni}_{0.5} \mathrm{Co}_{0.5} \mathrm{~S}_{\mathrm{y}}$ showed the largest Rct which demonstrates the lowest electron-transfer kinetics.
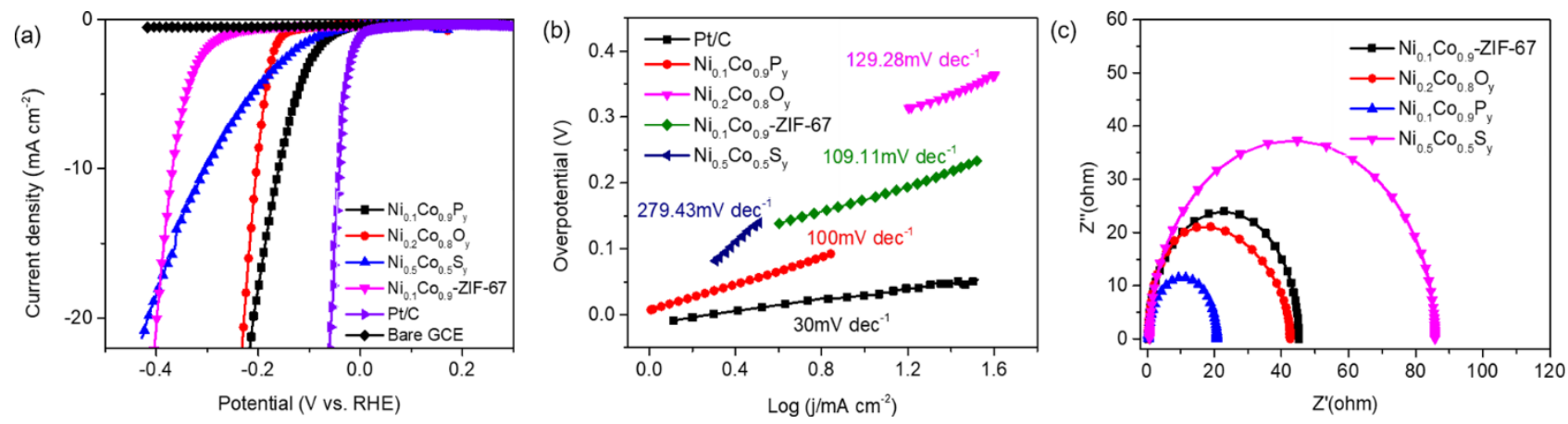

Figure 5. Polarization curves of $\mathrm{Ni}_{0.1} \mathrm{Co}_{0.9}-\mathrm{ZIF}-67, \mathrm{Ni}_{0.1} \mathrm{Co}_{0.9} \mathrm{P}_{\mathrm{y}}, \mathrm{Ni}_{0.2} \mathrm{Co}_{0.8} \mathrm{O}_{\mathrm{y}}, \mathrm{Ni}_{0.5} \mathrm{Co}_{0.5} \mathrm{~S}_{\mathrm{y}}$, commercial $\mathrm{Pt} / \mathrm{C}$ catalyst and bare GCE measured in alkaline media $(\mathrm{pH}=14 \pm 0.5,1 \mathrm{M} \mathrm{KOH})(\mathrm{a})$, Tafel plots (b) and Electrochemical Impedance Spectroscopy (EIS) Nyquist plots (c)

The following trend for the catalysts at the same current density of 10 or $20 \mathrm{~mA} \mathrm{~cm}^{-2}$ is observed: $\mathrm{Ni}_{0.1} \mathrm{Co}_{0.9} \mathrm{P}_{\mathrm{y}}>\mathrm{Ni}_{0.2} \mathrm{Co}_{0.8} \mathrm{O}_{\mathrm{y}}>\mathrm{Ni}_{0.5} \mathrm{Co}_{0 .} \mathrm{S}_{\mathrm{y}}>\mathrm{Ni}_{0.1} \mathrm{Co}_{0.9}$-ZIF-67. To evaluate the stability of the catalysts, longterm electrolysis in 1.0 M KOH is carried out. The four catalysts show almost the same LSV curve with negligible cathode current drop after 2000 cycles, which confirms their high stability for alkaline HER (Fig. S9). To get further insight into the structure-activity correlation between HER performance and different catalysts, a series of DFT calculations were performed (SI). For an ideal electrocatalyst, a moderate $\mathrm{H}$ adsorption free energy is close to zero $\left(\Delta \mathrm{G}_{\mathrm{H}^{*}} \approx 0\right)$, which is in favor of the adsorption and desorption steps, thus facilitating the proton-electron-transfer process. Therefore, proton adsorption free energy was adopted to correlate the HER performance. The results are illustrated in Fig.6 and the optimized adsorption structures are presented in Fig. S11. We firstly compared the H adsorption free energy of $\mathrm{Co}_{9} \mathrm{~S}_{8}, \mathrm{Co}_{3} \mathrm{O}_{4}$ and $\mathrm{CoP}$ (Fig. 6a), and the $\mathrm{H}$ adsorption free energy of $\mathrm{Co}_{9} \mathrm{~S}_{8}(1.01 \mathrm{eV}), \mathrm{Co}_{3} \mathrm{O}_{4}$ $(-0.74 \mathrm{eV})$ and $\mathrm{CoP}(0.09 \mathrm{eV})$ are similar with the experimental results. Due to the lowest $\mathrm{H}$ adsorption free energy, the CoP shows excellent HER performance. We further built the Ni doped CoP model to 
simulate the $\mathrm{Ni}_{1-\mathrm{x}} \mathrm{Co}_{\mathrm{x}} \mathrm{P}_{\mathrm{y}}$ (Fig. 6b), of which the $\Delta \mathrm{GH}^{*}$ are: $\mathrm{Co}_{0.7} \mathrm{Ni}_{0.1} \mathrm{P}(0.08197 \mathrm{eV}), \mathrm{Co}_{0.6} \mathrm{Ni}_{0.2} \mathrm{P}(0.09327$ $\mathrm{eV}$ ), and $\mathrm{Co}_{0.5} \mathrm{Ni}_{0.3} \mathrm{P}(0.116582 \mathrm{eV})$. As the $\mathrm{Ni}$ decreases, the $\mathrm{Ni}_{1-\mathrm{x}} \mathrm{Co}_{\mathrm{x}} \mathrm{P}_{\mathrm{y}}$ showed lower $\Delta \mathrm{GH}^{*}$ in the order $\mathrm{Co}_{0.5} \mathrm{Ni}_{0.3} \mathrm{P}>\mathrm{Co}_{0.6} \mathrm{Ni}_{0.2} \mathrm{P}>\mathrm{Co}_{0.7} \mathrm{Ni}_{0.1} \mathrm{P}$, which is in accordance with the experimental result demonstrating that the phosphide performance is superior in the sample with high Co: Ni ratio. In conclusion, the CoP shows superior HER performance in contrast to the $\mathrm{Co}_{9} \mathrm{~S}_{8}$ and $\mathrm{Co}_{3} \mathrm{O}_{4}$. The $\mathrm{Co}_{0.7} \mathrm{Ni}_{0.1} \mathrm{P}$ shows the highest electrochemical performances according to the DFT calculations, while sample $\mathrm{Co}_{0.9} \mathrm{Ni}_{0.1} \mathrm{P}_{\mathrm{y}}$ with best HER performance was obtained experimentally.

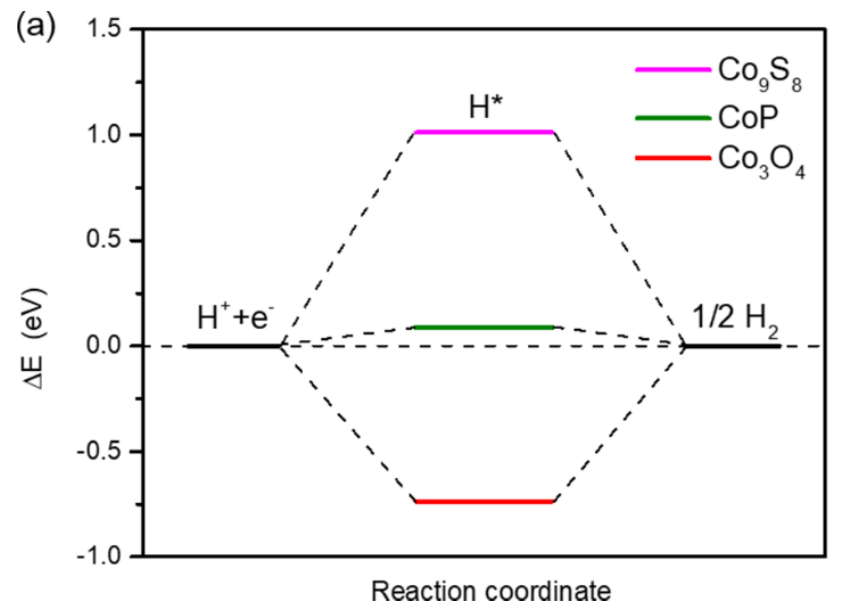

(b)

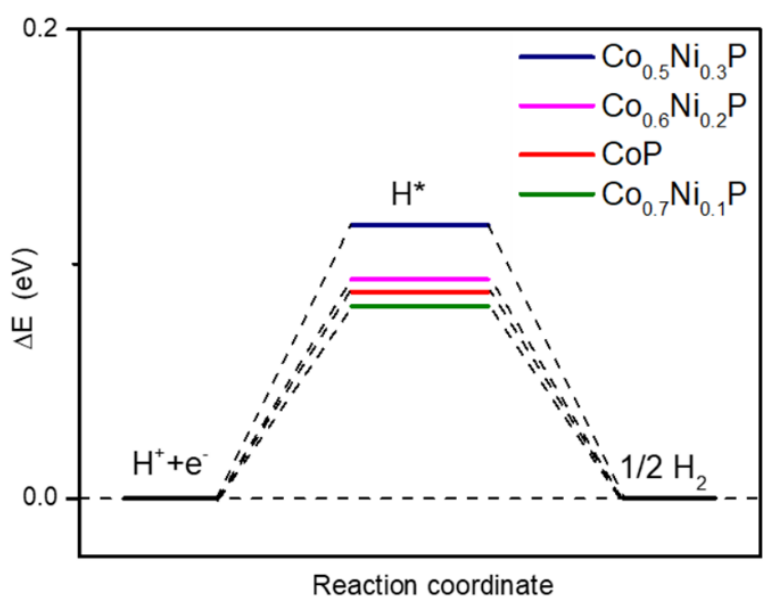

Figure 6. Calculated free energy diagram of the HER on the $\mathrm{Co}_{3} \mathrm{O}_{4}(110), \mathrm{Co}_{9} \mathrm{~S}_{8}(111), \mathrm{CoP}(101)$ (a), and $\mathrm{Co}_{0.5} \mathrm{Ni}_{0.3} \mathrm{P}, \mathrm{Co}_{0.6} \mathrm{Ni}_{0.2} \mathrm{P}, \mathrm{CoP}, \mathrm{Co}_{0.7} \mathrm{Ni}_{0.1} \mathrm{P}$ (b)

The electrochemical activity of the catalysts for HER are comparable and slightly improved than those reported in the open literature so far ${ }^{[11 \mathrm{a}, 18,27]}$. The HER activity of $\mathrm{Ni}_{0.1} \mathrm{Co}_{0.9} \mathrm{P}_{\mathrm{y}}$ in comparison with the materials already published are summarized in Table S4. The phosphides have high affinities for $\mathrm{H}_{2}$ and they could be suitable for HER electrocatalysis. The best performance of the $\mathrm{Ni}_{0.1} \mathrm{Co}_{0.9} \mathrm{P}_{\mathrm{y}}$ catalyst is attributed to the following reasons: (i) the nanosized bimetallic structure provide abundant active sites for the electrochemical reaction, (ii) $\mathrm{Ni}$ and $\mathrm{Co}$ atoms are atomically arranged in the $\mathrm{Ni}_{0.1} \mathrm{Co}_{0.9} \mathrm{P}_{\mathrm{y}}$, (iii) the electron transfer from $\mathrm{Ni}$ and $\mathrm{Co}$ to $\mathrm{P}$ improve the electron-donating ability of the catalyst, leading to the high HER activity, (iv) DFT results further indicate that the synergistic effect between Co and Ni with metal ratio of 9:1 in phosphide can increase the binding strength of $\mathrm{H}$, thus improving the electrocatalytic 
performance. Overall, the $\mathrm{Ni}_{0.1} \mathrm{Co}_{0.9} \mathrm{P}_{\mathrm{y}}$ has been considered as a highly efficient and stable electrocatalyst for HER.

\section{Conclusions}

In summary, nanosized homeotypic bimetallic $\mathrm{Ni}_{1-\mathrm{x}} \mathrm{Co}_{\mathrm{x}} \mathrm{O}_{\mathrm{y}}, \mathrm{Ni}_{1-\mathrm{x}} \mathrm{Co}_{\mathrm{x}} \mathrm{S}_{\mathrm{y}}$ and $\mathrm{Ni}_{1-\mathrm{x}} \mathrm{Co}_{\mathrm{x}} \mathrm{P}_{\mathrm{y}}$ catalysts were prepared from Ni1-xCox-ZIF-67 by temperature-programmed reactions with oxygen, sublimed sulfur and sodium hypophosphite, respectively. Compared to the monometallic Co-based materials, the homologous bimetallic $\mathrm{Ni}_{1-\mathrm{x}} \mathrm{Co}_{\mathrm{x}}-\mathrm{ZIF}-67, \mathrm{Ni}_{1-\mathrm{x}} \mathrm{Co}_{\mathrm{x}} \mathrm{O}_{\mathrm{y}}, \mathrm{Ni}_{1-\mathrm{x}} \mathrm{Co}_{\mathrm{x}} \mathrm{S}_{\mathrm{y}}$ and $\mathrm{Ni}_{1-\mathrm{x}} \mathrm{Co}_{\mathrm{x}} \mathrm{P}_{\mathrm{y}}$ catalysts exhibit better electrocatalytic activity for hydrogen production in alkaline water electrolysis.

The high HER activity of the $\mathrm{Ni}_{0.1} \mathrm{Co}_{0.9} \mathrm{P}_{\mathrm{y}}$ modified electrode is related to the appropriate nickelcobalt metal ratio, high crystallinity, and nickel-cobalt synergistic accelerating electron transfer from Ni and Co to $\mathrm{P}$. This correlation between the composition and properties of nickel-cobalt nanoparticles and their electrocatalytic performance for hydrogen evolution in alkaline media are the base for further design of better transition metals catalyst toward the HER.

\section{Experimental Section}

\section{Chemical and reagents}

Cobalt acetate $\left(\mathrm{Co}\left(\mathrm{CH}_{3} \mathrm{CO}_{2}\right)_{2} \bullet 4 \mathrm{H}_{2} \mathrm{O}\right)$, nickel acetate $\left(\mathrm{Ni}\left(\mathrm{CH}_{3} \mathrm{CO}_{2}\right)_{2} \bullet 4 \mathrm{H}_{2} \mathrm{O}\right)$, 2-methylimidazole $\left(\mathrm{C}_{4} \mathrm{H}_{6} \mathrm{~N}_{2}\right)$, triethylamine $\left(\left(\mathrm{C}_{2} \mathrm{H}_{5}\right)_{3} \mathrm{~N}\right)$, potassium hydroxide $\left(\mathrm{KOH}\right.$, pellets), thiourea $\left(\mathrm{CH}_{4} \mathrm{~N}_{2} \mathrm{~S}\right)$, nafion $(5$ wt\%), ethanol $\left(\mathrm{C}_{2} \mathrm{H}_{6} \mathrm{O}\right)$ were purchased from Sinopharm Chemical Reagent Co., Ltd. All reagents and solvents were used as received without further treatment.

Preparation of Co-ZIF-67: Co-ZIF-67 nanocrystals were synthesized following the procedure described by Wang et.al. ${ }^{[14 a]}$ with slight modification. In a typical synthesis, solution A was prepared by cobalt acetate $(0.4152 \mathrm{~g}, 0.00167 \mathrm{~mol})$ dissolved in $15 \mathrm{ml}$ distilled water. Solution B was prepared by 
dissolving 2-methylimidazole (1.3686 g, $0.0167 \mathrm{~mol})$ and TEA (1.6868 g, $0.167 \mathrm{~mol})$ in $15 \mathrm{ml}$ distilled water. Both solutions were stirred with $800 \mathrm{r} / \mathrm{min}$ for $30 \mathrm{~min}$. Then the two solutions were mixed in icewater bath for $10 \mathrm{~min}$. Purple crystals were collected by centrifugation and washed several times with distilled water and dried at $60{ }^{\circ} \mathrm{C}$ oven for $12 \mathrm{~h}$. The obtained samples were denoted as Co-ZIF-67.

Preparation of $\mathrm{Ni}_{\mathrm{x}} \mathrm{Co}_{1-\mathrm{x}}$-ZIF-67: the cobalt acetate in the synthesis precursor was replaced with a mixture of cobalt acetate and nickel acetate, the $\mathrm{Co} / \mathrm{Ni}$ molar ratios were adjusted from 9:1 to 1:1. The preparation of the $\mathrm{Ni}_{\mathrm{x}} \mathrm{Co}_{1-\mathrm{x}}-\mathrm{ZIF}-67$ was performed in ice-water bath for $10 \mathrm{~min}$. The washing and drying procedure were same as before. The obtained samples were denoted as $\mathrm{Ni}_{\mathrm{x}} \mathrm{Co}_{1-\mathrm{x}}-\mathrm{ZIF}-67$.

\section{Synthesis of mono- and bi- metallic $\mathrm{Ni}_{x} \mathrm{Co1}-\mathrm{x} \mathrm{O}_{y}, \mathrm{Ni}_{x} \mathrm{Co1}-\mathrm{x} \mathrm{S}_{\mathrm{y}}, \mathrm{Ni}_{\mathrm{x}} \mathrm{Co1-x} \mathrm{P}_{\mathrm{y}}$ catalysts}

Preparation of $\mathrm{Ni}_{\mathrm{x}} \mathrm{Co}_{1-\mathrm{x}} \mathrm{O}_{\mathrm{y}}$ : the $\mathrm{Ni}_{\mathrm{x}} \mathrm{Co}_{1-\mathrm{x}}-\mathrm{ZIF}-67$ samples were put into a muffle furnace and annealed at $800{ }^{\circ} \mathrm{C}$ for $4 \mathrm{~h}$ under air (ramping of $2{ }^{\circ} \mathrm{C} \mathrm{min}^{-1}$ ). The final black powder was collected at room temperature (the samples are donated as $\mathrm{Ni}_{\mathrm{x}} \mathrm{Co}_{1-\mathrm{x}} \mathrm{O}_{\mathrm{y}}$ ).

Preparation of $\mathrm{Ni}_{\mathrm{x}} \mathrm{Co}_{1-\mathrm{x}} \mathrm{S}_{\mathrm{y}}{ }^{[20 \mathrm{a}, 20 \mathrm{~b}]}: \mathrm{Ni}_{\mathrm{x}} \mathrm{Co}_{1-\mathrm{x}}-\mathrm{ZIF}-67(0.2 \mathrm{~g})$ and sublimed sulfur $(0.1 \mathrm{~g})$ were placed at two separate positions in a porcelain boat; the sublimed sulfur was placed at the upstream side of the furnace. The obtained samples were denoted as $\mathrm{Ni}_{\mathrm{x}} \mathrm{Co}_{1-\mathrm{x}} \mathrm{S}_{\mathrm{y}}$.

Preparation of $\mathrm{Ni}_{\mathrm{x}} \mathrm{Co}_{1-\mathrm{x}} \mathrm{P}_{\mathrm{y}}{ }^{[12 \mathrm{c}, 26,28]}$ : $\mathrm{Ni}_{\mathrm{x}} \mathrm{Co}_{1-\mathrm{x}}-\mathrm{ZIF}-67(0.2 \mathrm{~g})$ and $\mathrm{NaH}_{2} \mathrm{PO}_{2} \bullet \mathrm{H}_{2} \mathrm{O}(1 \mathrm{~g})$ were placed at two separate positions in a porcelain boat; $\mathrm{NaH}_{2} \mathrm{PO}_{2} \bullet \mathrm{H}_{2} \mathrm{O}$ was placed at the upstream side of the furnace. The molar ratio of $\mathrm{Co} / \mathrm{P}$ was 1:20. The obtained samples were denoted as $\mathrm{Ni}_{\mathrm{x}} \mathrm{Co}_{1-\mathrm{x}} \mathrm{P}_{\mathrm{y}}$.

\section{Characterization}

The structure of the samples was characterized by X-ray powder diffraction (Siemens D5005 diffractometer) with $\mathrm{Cu} \mathrm{K \alpha}$ radiation $(\lambda=1.5418 \AA)$ in Bragg-Brentano $(\theta \sim 2 \theta)$ configuration. The structure and morphology of the as-prepared samples were characterized by a field emission scanning electron microscope (JEOL JSM-7900F). Transmission electron microscopy (TEM) images were 
obtained using a JEM 2100 transmission electron microscope operating at $200 \mathrm{kV}$. The distribution of the elements of the samples was measured by EDS-SEM using JEOL-7900F SEM and Oxford Instruments $\mathrm{X}-\mathrm{MaxN}$ Energy-Dispersive Spectroscopy. The hydrogen and nitrogen adsorption-desorption experiments were performed at 77K using Quantachrome autosorb iQ3 gas sorption analyzer. The external surface area was determined by the Brunauer-Emmett-Teller Method (BET).The infrared (IR) spectra of samples were collected by NEXUS FT-IR using the KBr technique. Chemical composition of the as-synthesized samples were characterized by X-ray photoelectron spectroscope with $\mathrm{PH} 5000$ Versaprobe system using monochromatic $\mathrm{Al} \mathrm{K} \alpha$ radiation $(\mathrm{h} v=1486.6 \mathrm{eV})$. Inductively Coupled Plasma (ICP) was performed by Agilent ICPOES 720.

\section{Electrochemical Measurements}

All electrochemical measurements were carried out in nitrogen-purged $1 \mathrm{M} \mathrm{KOH}$ solution $(\mathrm{pH}=14 \pm 0.5)$ at room temperature on a $\mathrm{CHI} 660 \mathrm{E}$ electrochemical workstation using a standard threeelectrode system: a saturated calomel electrode (SCE) used as a reference electrode, a carbon rod used as a counter electrode, and a glassy carbon electrode (GCE, $0.1256 \mathrm{~cm}^{2}$, geometric area) used as a working electrode. The working electrode was prepared as follows. Typically, the catalytic powder (3.6 mg) and activated carbon $(0.09 \mathrm{mg})$ are added into a mixture of $1 \mathrm{~mL}$ ethanol and $80 \mu \mathrm{L}$ Nafion $(5 \mathrm{wt} \%)$ and sonicated for 40 min to obtain a homogeneous mixture further called ink. Then $(10 \mu \mathrm{L})$ of the catalyst ink was deposited onto the GCE surface (loading $0.358 \mathrm{mg} \mathrm{cm}^{-2}$ ).

The polarization curves were obtained by linear voltammetry sweeping (LSV) from $0.27 \mathrm{~V}$ to -0.53 $\mathrm{V}$ (vs RHE) with a scan rate of $10 \mathrm{mV} \mathrm{s}^{-1}$ in $1 \mathrm{M} \mathrm{KOH}$. Alternating current (AC) impedance measurements were carried out at -0.3 and $-0.41 \mathrm{~V}$ from $100 \mathrm{kHz}$ to $0.1 \mathrm{~Hz}$. The stability of the catalysts was characterized under continuous cyclic voltammetry (CV) measurements from -0.05 to $0.2 \mathrm{~V}$ (vs RHE) at a sweep rate of $50 \mathrm{mV} \mathrm{s}^{-1}$. During the experiments, a flow of nitrogen was maintained over the electrolyte 
to eliminate dissolved oxygen. All results were calibrated with respect to the reversible hydrogen electrode $(\mathrm{RHE})$ by $\mathrm{E}(\mathrm{RHE})=\mathrm{E}(\mathrm{V}$ vs SCE $)+0.245 \mathrm{~V}+0.059 \mathrm{pH}{ }^{[14 \mathrm{a}]}$.

Theoretical calculations were performed using Vienna ab initio simulation packages (VASP) based on density functional theory (DFT). ${ }^{[29]}$ The core and valence electrons were described by the projector augmented wave (PAW) pseudopotentials. The generalized gradient approximation (GGA) in the scheme of proposed by Perdew, Burke, and Ernzerhof (PBE) was adopted to express the exchange correlation interactions with a cut off energy of $400 \mathrm{eV} \cdot{ }^{[30]} \mathrm{A} 12 \AA$ vacuum region was used to simulate the adsorption and all the top two layers of atoms in the structure are allowed to relax. The convergence of energy and forces were set to $1 \times 10-5 \mathrm{eV}$ and $0.03 \mathrm{eV}$, respectively. The free energy of hydrogen adsorption $\left(\Delta \mathrm{GH}^{*}\right)$ can be calculated as follows:

$$
\Delta \mathrm{G}\left(\mathrm{H}^{*}\right)=\Delta \mathrm{E}+0.24 \mathrm{eV}
$$

And $\Delta \mathrm{E}$ is the adsorption energy, with defined as follows:

$$
\Delta \mathrm{E}=\mathrm{E}(\text { substrate }+ \text { adsorbate)-Esubstrate-Eadsorbate }
$$

\section{Acknowledgements}

The authors are grateful to the National Natural Science Foundation of China [Grant No. U1862118], funding from Thousand Talents Program, China [WQ20152100316], the Fundamental Research Funds for the Central Universities, China [No. 18CX05018A], the State Key Laboratory of Advanced Technology for Materials Synthesis and Processing (Wuhan University of Technology), China [No. 2018KE-13], the Foundation Franco-Chinoise pour la Science et Applications (FFCSA), and the Sino-French LIA “Zeolite”.

Keywords: ZIF-67 $・$ Ni-Co-doping $\bullet$ organized bimetallic atomic arrangement $\bullet$ Hydrogen evolution reaction 
ACS Catal. 2017, 7, 7126-7130.

[2] a) H. Ito, T. Maeda, A. Nakano, Y. Hasegawa, N. Yokoi, C. M. Hwang, M. Ishida, A. Kato, T. Yoshida, Int. J. Hydrogen Energy 2010, 35, 9550-9560; b) T. Asefa, Acc. Chem. Res. 2016, 49, 1873-1883.

[3] a) X. Li, Y. Fang, X. Lin, M. Tian, X. An, Y. Fu, R. Li, J. Jin, J. Ma, J. Mater. Chem. A 2015, 3, 17392-17402; b) Y. Li, J. Liu, C. Chen, X. Zhang, J. Chen, ACS Appl. Mater. Interfaces 2017, 9, 5982-5991; c) P. Chen, K. Xu, Z. Fang, Y. Tong, J. Wu, X. Lu, X. Peng, H. Ding, C. Wu, Y. Xie, Angew. Chem. 2015, 54, 14710-14714; d) C. Guan, X. Liu, A. M. Elshahawy, H. Zhang, H. Wu, S. J. Pennycook, J. Wang, Nanoscale Horiz. 2017, 2, 342-348.

[4] T. Ling, D. Y. Yan, H. Wang, Y. Jiao, Z. Hu, Y. Zheng, L. Zheng, J. Mao, H. Liu, X. W. Du, M. Jaroniec, S. Z. Qiao, Nat. Commun. 2017, 8, 1509.

[5] J.-B. Raoof, S. R. Hosseini, R. Ojani, S. Mandegarzad, Energy 2015, 90, 1075-1081.

[6] T. R. Hellstern, J. D. Benck, J. Kibsgaard, C. Hahn, T. F. Jaramillo, Adv. Energy Mater. 2016, 6, 1501758.

[7] J. Yu, Q. Li, Y. Li, C.-Y. Xu, L. Zhen, V. P. Dravid, J. Wu, Adv. Funct. Mater. 2016, 26, 7644-7651.

[8] G. Anandhababu, Y. Huang, D. D. Babu, M. Wu, Y. Wang, Adv. Funct. Mater. 2018, 28, 1706120.

[9] aX. Chen, M. Cheng, D. Chen, R. Wang, ACS Appl. Mater. Interfaces 2016, 8, 3892-3900; b2013.

[10] C. Zhu, S. Fu, Q. Shi, D. Du, Y. Lin, Angew. Chem. 2017, 56, 13944-13960.

[11] a) Q. Chen, J. Miao, L. Quan, D. Cai, H. Zhan, Nanoscale 2018, 10, 4051-4060; b) Z. Peng, D. Jia, J. Tang, Y. Wang, Y. Wang, L. Zhang, G. Zheng, J. Mater. Chem. A 2014, 2, 10904; c) J. Yao, P. Xiao, Y. Zhang, M. Zhan, F. Yang, X. Meng, J. Alloys Compd. 2014, 583, 366-371.

[12] a) P. He, X.-Y. Yu, X. W. Lou, Angew. Chem. 2017, 129, 3955-3958; b) Y. Zhao, G. Fan, L. Yang, Y. Lin, F. Li, Nanoscale 2018, 10, 13555-13564; c) X. Liang, B. Zheng, L. Chen, J. Zhang, Z. Zhuang, B. Chen, ACS Appl. Mater. Interfaces 2017, 9, 23222-23229.

[13] Y. Lü, W. Zhan, Y. He, Y. Wang, X. Kong, Q. Kuang, Z. Xie, L. Zheng, ACS Appl. Mater. Interfaces 2014, 6, 4186-4195. 
[14] a) M. Wang, X. Jiang, J. Liu, H. Guo, C. Liu, Electrochim. Acta 2015, 182, 613-620; b) J. Zhou, Y. Dou, A. Zhou, R.-M. Guo, M.-J. Zhao, J.-R. Li, Adv. Energy Mater. 2017, 7, 1602643.

[15] S. Ding, Q. Yan, H. Jiang, Z. Zhong, R. Chen, W. Xing, Chem. Eng. J. 2016, 296, 146-153.

[16] F. Bai, Y. Xia, B. Chen, H. Su, Y. Zhu, Carbon 2014, 79, 213-226.

[17] X. Yang, J. Chen, Y. Chen, P. Feng, H. Lai, J. Li, X. Luo, Nano-micro Lett. 2018, 10, 15.

[18] T. Gholami, M. Salavati-Niasari, S. Varshoy, Int. J. Hydrogen Energy 2017, 42, 5235-5245.

[19] A. M. Pornea, M. W. Abebe, H. Kim, Chem. Phys. 2019, 516, 152-159.

[20] a) J. He, Y. Chen, A. Manthiram, Energy Environ. Sci. 2018, 11, 2560-2568; b) J. Huang, X. Tang, K. Liu, Z. Li, Mater. Lett. 2018, 210, 88-91; c) J. Yang, G. Zhu, Y. Liu, J. Xia, Z. Ji, X. Shen, S. Wu, Adv. Funct. Mater. 2016, 26, 4712-4721.

[21] K.-Y. A. Lin, H.-A. Chang, J. Taiwan Inst. Chem. Eng. 2015, 53, 40-45.

[22] C.-W. Tang, C.-B. Wang, S.-H. Chien, Thermochim. Acta 2008, 473, 68-73.

[23] J. Li, G. Wei, Y. Zhu, Y. Xi, X. Pan, Y. Ji, I. V. Zatovsky, W. Han, J. Mater. Chem. A 2017, 5, $14828-14837$.

[24] J. Wang, L. Li, X. Chen, Y. Lu, W. Yang, J. Mater. Chem. A 2016, 4, 11342-11350.

[25] a) I. S. Amiinu, Z. Pu, X. Liu, K. A. Owusu, H. G. R. Monestel, F. O. Boakye, H. Zhang, S. Mu, Adv. Funct. Mater. 2017, 27, 1702300; b) R. Wang, L. Wang, W. Zhou, Y. Chen, H. Yan, Z. Ren, C. Tian, K. Shi, H. Fu, ACS Appl. Mater. Interfaces 2018, 10, 9999-10010; c) X. R. Wang, J. Y. Liu, Z. W. Liu, W. C. Wang, J. Luo, X. P. Han, X. W. Du, S. Z. Qiao, J. Yang, Adv. mater. 2018, $30, \mathrm{e} 1800005$.

[26] M. Liu, J. Li, ACS Appl. Mater. Interfaces 2016, 8, 2158-2165.

[27] a) J. D. Benck, T. R. Hellstern, J. Kibsgaard, P. Chakthranont, T. F. Jaramillo, ACS Catal. 2014, 4, 3957-3971; b) L. Chen, J. W. Ye, H. P. Wang, M. Pan, S. Y. Yin, Z. W. Wei, L. Y. Zhang, K. Wu, Y. N. Fan, C. Y. Su, Nat. Commun. 2017, 8, 15985; c) S. Dou, X. Li, L. Tao, J. Huo, S. Wang, Chem. Commun. 2016, 52, 9727-9730; d) B. Y. Guan, L. Yu, X. W. D. Lou, Adv. Sci. 2017, 4, 1700247; e) B. Hu, Z. Jing, J. Fan, G. Yao, F. Jin, Catal. Today 2016, 263, 128-135; f) M. Jahan, 
Z. Liu, K. P. Loh, Adv. Funct. Mater. 2013, 23, 5363-5372.

[28] a) P. Jiang, Q. Liu, C. Ge, W. Cui, Z. Pu, A. M. Asiri, X. Sun, J. Mater. Chem. A 2014, 2, 14634;

b) Y. Li, H. Zhang, M. Jiang, Y. Kuang, X. Sun, X. Duan, Nano Res. 2016, 9, 2251-2259.

[29] a) G. Kresse, J. Furthmüller, Comput. Mater. Sci. 1996, 6, 15-50; b) G. Kresse, J. Furthmüller, Phys. Rev. B 1996, 54, 11169-11186.

[30] a) G. Kresse, D. Joubert, Phys. Rev. B 1999, 59, 1758-1775; b) P. E. Blöchl, Phys. Rev. B 1994, 50, 17953-17979. 